\title{
Violence and Youth
}

\section{Youth Violence Prevention}

I ncreasing violence among young people is a particularly alarming problem in the region. ${ }^{2}$ Youth are at a higher risk of being victims and perpetrators of violence, including physical injury, sexual abuse, neglect, emotional and verbal abuse. Yet juvenile violence can be prevented and juvenile offenders can be rehabilitated. This technical note calls attention to a growing body of scientifically credible evidence that can be used to implement sound and cost-effective violence prevention programs ${ }^{3}$.

\section{The scope of the problem}

Young people as victims of violence

- Approximately $28.7 \%$ of homicides in Latin America occur among youths between the ages of 10 and 19. Homicide is the second leading cause of death in this age group in 10 of the 21 countries in the region with populations greater that one million (Weaver and Maddalenno, 1999). In Venezuela, for example, $95 \%$ of homicide victims are males, of which 54\% are younger than 25. Youth homicide rates are almost three times greater than national homicide rates (see Table 1).

- Youth violence is responsible for many nonfatal injuries and disabilities. PAHO estimates that for every child and adolescent that dies due to trauma in Latin America, 15 are left severely injured by violence.

- In the United States, violence is a leading cause of nonfatal injuries among young people. In 1995,

1 This note was written by María Loreto Biehl of the SocialDevelopment Division. It is largely based on the paper "What Works in Youth Violence Prevention", by Dewey G. Cornell. University of Virginia, Virginia Youth Violence Project. The IDB thanks the author for authorizing the partial reproduction and translation into Spanish of the paper. The original document can be found at

Curry.edschool.virginia.edu/curry/centers/youthviolence.

2 The Pan American Health Organization (1994) and the World Health Organization define adolescence as the period between 10 and 19 years of age and youth as the period between 15 and 24 years. The definitions vary enormously between researchers, thus data is not comparable. Using this age range, adolescents and youth make up $31.6 \%$ of the total population in the Americas.

3 This note reports research mostly from US. Thus, some programs may not be applicable to the Latin American reality. almost 400,000 persons aged 15 to 19 years old went to emergency rooms because of interpersonal violence.

- High rates of sexual abuse and rape, especially among the youngest adolescent females, are only beginning to be reported in Latin America and the Caribbean. The Caribbean Adolescent Health Survey found that by the time they were 16 to 18 years old, one in eight adolescents had been sexually abused; females were twice as likely as males to be victims of such abuse (Weaver and Maddalenno, 1999).

\section{Young people as perpetrators of crime} and violence

- Available data for Latin America show that in 1994 17\% of all homicides were perpetrated by minors (Weaver and Maddalenno, 1999).

- A study done by the Venezuelan police between 1994 and 1996 showed that $40.3 \%$ of those detained were minors (Briceño et al., 1999).

- In the United States, nearly $20 \%$ of the people arrested for violent crimes in 1994 were younger

Table 1:

Homicide rates for Selected Countries

\begin{tabular}{lccc} 
& Year & $\begin{array}{c}\text { Homicide } \\
\text { rates } 15 \text { to } 24 \\
\text { years }\end{array}$ & $\begin{array}{c}\text { Total } \\
\text { homicides } \\
\text { rates }\end{array}$ \\
\hline Venezuela & 1994 & 66.1 & 28.8 \\
\hline Brazil & 1995 & 48.6 & 30.6 \\
\hline Mexico & 1995 & 24.3 & 20.2
\end{tabular}

Source: Waiselfisz, 1998. 
than 18 years old. Of 22,133 suspects arrested for rape, $37 \%$ were between the ages of 15 and 24 . Of 94,034 suspects arrested for robbery and 372,422 arrested for aggravated assault, $57 \%$ and $34 \%$ respectively, were 15 to 24 years old (Center for Diseases Control,1997).

\section{Causes of Youth Violence}

Violence Violence does not spontaneously appear in adolescence. General risk factors for violence are discussed in previous technical notes, but research shows that there are a number of specific individual and social factors that increase the probability of violence during adolescence and young adulthood. The most relevant factors are clustered in four areas in table 2.

\section{Table 2:}

\section{Causes of Youth Violence}

INDIVIDUAL

History of Early Aggression

Social Cognitive Deficits

Family Violence and Child Abuse

Use of Alcohol and Drugs

\section{FINDINGS}

* A 22-year follow-up study revealed that aggressive behavior of boys in early childhood is predictive of serious antisocial behavior in adulthood, including criminal offenses, spouse abuse, and a tendency toward severe punishment of children (Eron, Huesmann, Lefkowitz and Walder, 1984).

* Lewis (1992) studied "intrinsically vulnerable children" with cognitive, psychiatric, or neurological impairments. He found that neuropsychiatrically impaired children, by virtue of their hyperactivity and impulsiveness, were more likely to be abused by adults in their family settings. A longitudinal study in Sweden showed that boys with restlessness and concentration difficulties were five times more likely to be arrested for violence than boys wtihout these caracteristics (Klinteberg, et al., 1993).

* Child maltreatment, which includes physical, sexual and emotional abuse as well as neglect, is an important common factor among youths who have committed murder (Garbarino, 1995). A study in the U.S. found that childhood abuse and neglect increase the likelihood of arrest as a juvenile by $59 \%$ and as an adult by $28 \%$. It also increases the chances of commiting a violent crime by 30\% (Samuels, 2001).

* The predictors for juvenile violence and delinquency differ according to age. Substance abuse is a good predictor of future violence for children ages 6-11, but one of the poorest predictors for children ages 12-14 (Hawkins et al, 2000).

\section{FAMILY}

Poor Monotoring or

Supervision of Children and Poor Emotional Attachment to Parents or Caregivers
* A study of 201 boys in the U.S. compared home atmosphere with the boys criminal records 30 years later. Multiple regression analysis indicated that six variables describing home atmosphere in childhood account for a significant proportion of the variance in the number of convictions for serious crimes. The variables were: mother's self-confidence, father's deviance, parental aggressiveness, maternal affection, parental conflict, and supervision. The three most direct measures 


\section{FAMILY}

\section{Poor Monotoring or Supervision of Children and Poor Emotional Attachment to Parents or Caregivers}

\section{Early Childbearing}

(childrearing supervision, mother's affection and parental conflict) accounted for a quarter of the variance in number of convictions for serious crimes, after effects of both social status and parental characteristics had been controled (McCord, 1979).

* Wells and Rankin (1988) reported that boys with very strict parents showed the most violence and boys with very permissive parents showed the second highest level of violence. Parental punitiveness and inconsistency also predicted violence.

* Children born to unprepared parents are more likely to be abused and, as a result, are more likely to victimize others later in life. Babies born to teenage parents are at increased risk for a variety of health threatening occurrences including physical, sexual and mental abuse, economic and educational deprivation, and neglect (Zabin, 1995).

\section{PEERS/SCHOOL}

\section{Association with Peers Engaged in High-Risk or Problem Behavior}

Low Commitment to school, Academic Failure, Dropping out of school.
* When youths have certain social experiences, their risk of involvement with violence increases. These experiences include access to firearms, involvement with alcohol and drugs, involvement with antisocial groups including delinquent gangs and violent mobs, and exposure to violence in the media.

* Delinquent peers may have a greater influence on later violence during adolescence than they do earlier in development. Research has shown that adolescentes whose peers disapproved of delinquent behavior were less likely to report having commited delinquent acts, including sexual assault (Hawkins et al, 2000).

* Poor academic achievement has consistently predicted later delinquency (Maguin and Loeber, 1996, Denno, 1990). In the Caribbean Health Survey, teenagers with difficulty learning in school were more likely to fight with weapons and attempt suicide (Weaver and Maddalenno, 1999).

\section{NEIGHBORHOOD/ COMMUNITY}

\section{Poverty and Diminished} Economic Opportunity

\section{Community Disorganization}

* Being raised in poverty has been found to contribute to a greater likelihood of involvemente in crime and violence (Sampson and Lauritsen, 1994). Poverty is often related to youth aggression because of increased stress and feelings of hopelessness that may arise from chronic unemployment. (American Psychological Association, 1997; Weaver and Maddalenno, 1999)

* Community factors including poverty, low neighborhood attachment and community disorganization, the availability of drugs and firearms, lack of social services, and exposure to violence may contribute to crime and violence (Hawkins et al, 2000) 
Box 1:

Socially Excuded Youth: The Gang Phenomenon

"Youth gangs are among the main features of the new landscape of violence in Latin America and the Carribbean. Whatever the name they are know by-pandillas, maras, bandas, galeras, quadrillas, barras, chapulines-they are common thoughout the region, and are recognized as a serious social develpment problem by all levels of society (Rodgers, 1999)".

No one circumstance is responsible for gang formation, but conditions like discrimination, poverty and lack of a support network increase the possibilities (Glick,1992). When young people encounter the systematic denial of privileges and opportunities and are denied access to power and resources, they will often form their own anti-establishment group. These risk factors are consistent with social ecology theory that states that gangs are partial replacements for crucial social institutions such as the family, school, or labor market, which have been weakened or are disfunctional. A recent study in El Salvador stresses the importance of family factors in joining gangs: $82.9 \%$ of families with "mareros" live in poverty, $72.7 \%$ of the households are headed by single mothers, 33\% of the parents work more than nine hours a day and are not able to suppervise their children, and physical violence is present in $80 \%$ of the households (Santa Cruz, et al, 2001).

Most social scientists and criminologists agree that the most fruitful strategies for dealing with gangs are those that emphasize prevention and intervention instead of suppression and enforcement (Goldstein and Huff, 1993; Conley, 1993; Winfree, Mays and Vigil-Backstrom, 1994; Father Boyle, 1996).

A recent World Bank literature review (Rodgers, 1999) points to five gang characteristics that can be helpful for program and policy design:

Poverty. Most youth gangs in Latin America and the Caribbean tend to emerge in the context of urban poverty, although there are some notable exceptions (such as the Peruvian pandillas of "pitucos", which originate in the wealthier neighborhoods of Lima).

Particularism. Youth gangs in Latin America an the Caribbean are significantly different from country to country in their organization, structure, logic, dynamics and activities. Local conditions affect both the formation of youth gangs and their behavioral patterns.

Community Links. Some youth gangs have strong links to their local communities and do not direct their violence or their criminality toward them. But others have weak links and their illegal and violent activities take place within their own communities.

Drugs. Youth gangs involved in drug traffiking (as opposed to drug consumption, which is almost a given among youth gang members) tend to be more violent than those who are not. However, youth gangs that are not involved in drug trafficking can also display extremely violent behavior.

Migration. Post-war return migration and the increasing deportation of illegal aliens from the United States have become important factors in the formation of youth gangs in some Latin American countries during the late 1990s and in the adoption of more violent behavior.

Source: Rodgers, 1999; Concha, et al., 2001; CDC, 1999. 


\section{Youth Violence Generates Significant Economic Costs}

1 The premature death of young people due to violence is the primary cause of potential years of life lost (PYLL) ${ }^{4}$ among adolescents and youth in most countries in the region, resulting in an average loss of 30 to 40 years per death. The direct economic cost of death and disability as a result of violent acts is estimated at $\$ 10$ billion annually (Weaver and Maddalenno, 1999).

\section{Youth: A Window of Opportunity}

Understanding the factors that place young people at risk for violence is an important first step in violence prevention. The next essential step is to design interventions or programs to address these risk factors and evaluate the potential effectiveness of those interventions. It is important to note that no one strategy will prove effective for all youth or all settings. Programs that can reduce violent crime, by even 10 to 20\%, are likely to be cost-effective, in light of the high cost of juvenile crime for victims, communities and the criminal justice system (Cornell, 2000).

Even the best validated program will not succeed if it is not adequately funded and faithfully implemented by competent staff. A treatment program must be sufficiently well specified in training manuals and guides or through supervisory oversight by qualified practitioners, so that it can be replicated in a new setting. Generally, programs must demonstrate adequate treatment fidelity; that is, they must faithfully implement the actual treatment program as it was designed. All too often program managers have rushed to implement new treatments without adequate training and preparation. In such a case, failure is the result of poor implementation, not an inadequate treatment model (for example, see Henggeler, Melton, Brondino, Scherer and Hanley, 1997).

\section{Effective Prevention Strategies}

Violent behavior is preventable. It develops slowly, with risk factors gradually accumulating over many years before violent behavior emerges. This pattern presents professionals with multiple opportunities to intervene. Some examples are presented below, divided into community-wide, family- focused and school-based interventions. For those cases for which the University of Colorado has identify best practice programs (term "blueprint," see Box 2) these programs are presented in a text box.

4 Potential years of life lost due to a particular cause is the overall sum of the years lost to premature death, as compared to the additional years these persons would have lived had they lived to a normal life expectancy.

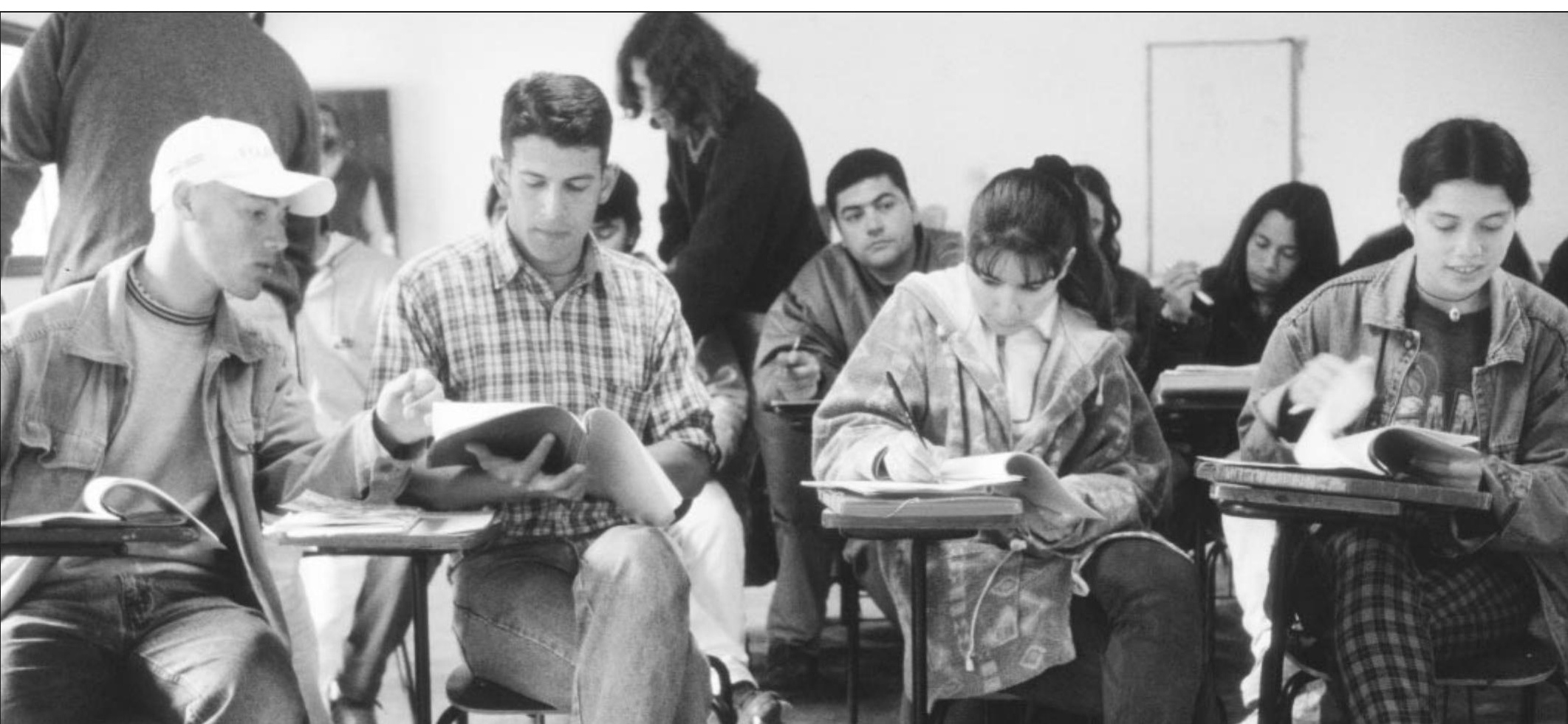


Box 2:

\section{Blueprints for Violence Prevention}

The Center for the Study and Prevention of Violence (CSPV) at the University of Colorado launched the Blueprints for Violence Prevention program to identify and replicate effective youth violence prevention programs across the United States. More than 500 programs were reviewed and 11 were selected acording to three main selection criteria: evidence of deterrent effect when using a strong research design, sustained effects and multiple site replications. The 11 programs selected have been demostrated effective in reducing violent crime, delinquency, substance abuse and pre-delinquent aggression (Mihalic et al, 2001).

For detailed information on these programs you can visit: Blueprintseries.at http://www.ncjrs.org/pdffiles1/ojjdp/187079.pdf

\begin{tabular}{lll} 
Community-wide & Family-focused & School-based \\
Mentoring & Parent education & Conflict resolution training \\
\hline Supervised recreation & Family therapy & Violence prevention counseling \\
\hline Policing & Preschool programs & Bullying reduction \\
\hline & & Social competence development \\
\hline
\end{tabular}

\section{Community-Wide Strategies}

\section{Mentoring}

Mentoring is a relatively inexpensive approach in which adult volunteers spend time each week with children or adolescents, typically engaging in recreational or educational activities. Despite the widespread popularity of mentoring, there has been relatively little research on the characteristics of successful mentors or successful mentoring relationships. A

\section{Blueprint:}

\section{Big Brothers/Big Sisters of America}

- The BBBSA provides qualified mentors to youths between the ages of 6 and 18, many of whom come from disadvantaged single-parent households.

- The mentor meets with the matched child at least three times per month for 3 to 5 hours each time. Together they participate in pleasurable activities "that enhance communication skills, develop relationship skills, and support positive decision-making."

- Big Brothers/Big Sisters program resulted in a $46 \%$ reduction in drug use, a 32\% reduction in hitting people, and a 52\% reduction in truancy (Grossman and Garry, 1997; Tierney and Grossman, 1995). descriptive study by Morrow and Styles distinguished between developmental and prescriptive styles of mentoring. Developmental mentors were more flexible and relationship-focused, while prescriptive mentors were more directive and tended to prescribe activities and topics of discussion. At follow-up nine months later, developmental mentors were more likely to still be working with their little brothers/sisters while most prescriptive relationships had terminated.

\section{Supervised Recreational Programs}

Peak times for juvenile crime are during the hours immediately after school (Sickmund, Snyder and Poe-Yamagata, 1997). The probability of a juvenile prepetrating an offense at 3 p.m. on a school day is over three times greater than it is at noon or midnight. Many youth are unsupervised after school because their parents are at work. The lack of coordination between school and work is an underlying structural problem that affects juvenile crime control. For this reason, after-school programs hold great potential value and deserve serious consideration in community prevention planning.

Most recreational programs have not been adequately tested. However, several controlled studies have found that well-supervised after-school recreational programs substantially reduce juvenile crime, drug use and vandalism. The Boys and Girls Club recreation and drug prevention program (Schinke, Orlandi and Cole, 1992) proved effective in two 


\section{Technical Note 10}

studies conducted in a series of public housing projects in the U.S. A Canadian study (Jones and Offord, 1989) of another intensive after-school program (using sports, music, dancing and scouting) yielded a $75 \%$ reduction in juvenile arrests, while arrests at a comparison site rose by $67 \%$.

\section{Policing}

Law enforcement leading to the arrest and incarceration of gang leaders has been successful for the dangerous communities with criminally active gangs. Although new leaders may emerge in some cases, in many instances gangs have been neutralized or eradicated (Bureau of Justice Assistance, 1997).

Recently, the National Institute of Justice (NIJ; Sherman et al., 1997) released a report of "what works" in preventing crime, based on reviews of hundreds of studies. Among the most effective policing strategies are:

- increased patrol of high-crime street corners

- arrests of serious repeat offenders

- arrests of drunk drivers.

Community policing is a broad term and some programs labeled as community policing are not effective (Sherman et al., 1997). The most effective community policing programs have strong community participation in establishing priorities and a problem-oriented focus. Also noteworthy is the new research emphasis on the importance of strengthening police credibility and legitimacy with the general public, which suggests that from a prevention perspective it is important for police officers to maintain trust and respect through the quality of their everyday interactions with citizens (Tyler, 1990). (For more information on community policing see note \#9.)

\section{Family-Focused Strategies}

\section{Parent Education}

Violence is a learned behavior, and children learn it mostly at home. On the prevention side, parent education is key. Some examples are:

Discipline training: an extensive literature review on parent training demonstrated that training the parents in less coercive discipline measures led to less violence against their children (Xxxx,1999).
Parenting skills for adolescents: another approach is to teach parenting skills to young people in schools before they become parents. Zoline and Jason reported that such programs could produce changes in knowledge and expectations among young men and women (Xxxx, p. 341)

\section{Parents and Media Violence}

As part of parent education, parents should also be encouraged to limit their children's exposure to violent television shows, movies, and video games. Despite mixed public opinion and objections by the media industry, there is extensive, conclusive research establishing that television violence has a detrimental effect on children (American Psychological Association, 1997; Donnerstein, Slaby and Eron, 1994; Hughes and Hasbrouck, 1996). Numerous formal experiments in clinical settings and schools, as well as long-term prospective field studies following young children into adulthood, demonstrate that exposure to media violence increases aggressive behavior. Among the effects of media violence are that children learn to expect and anticipate violence in their daily life, they are desensitized to violence and may even develop positive attitudes toward the use of violence, and they may fail to fully appreciate the negative consequences of violence. In some cases they engage in violence because they believe it is a source of social status, or an effective way to solve problems.

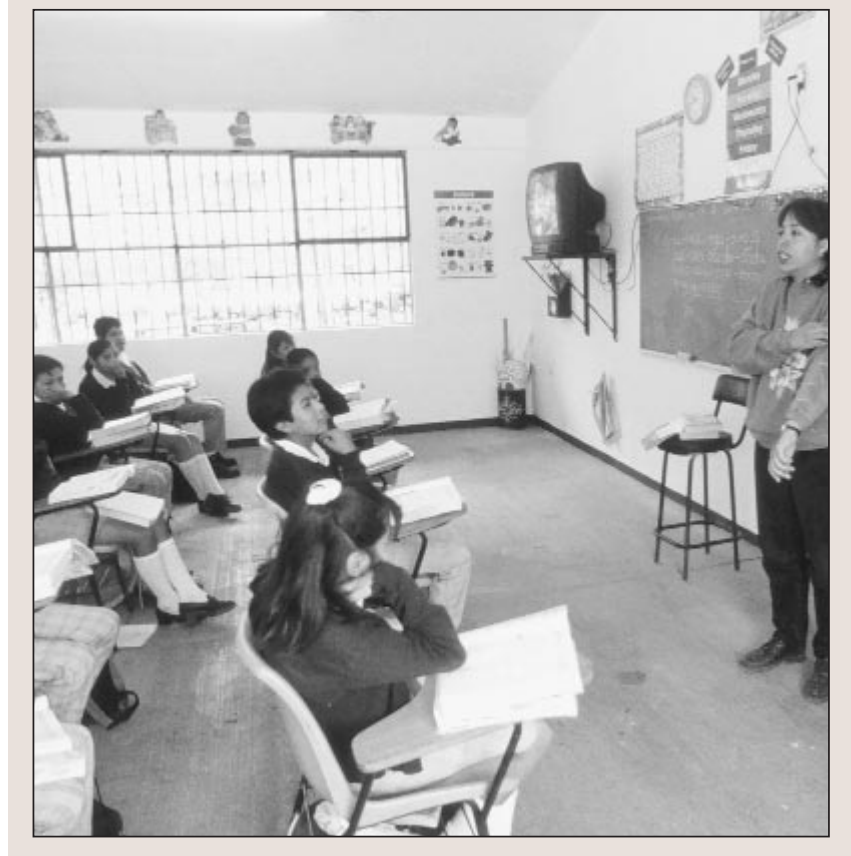


Violence is also learned through experience. Children who witness or are victims of abuse are more likely to engage in violent behavior themselves. Child abuse prevention and treatment is discussed in Technical Note $\# 11$.

\section{Blueprint: \\ The Incredible Years Series}

- The program is a comprehensive set of curricula for parents, teachers, and children that are designed to promote social competence and prevent, reduce, and treat behavioral problems in young children.

- The program is based on the understanding that early aggression patterns in children lead to later violence and crime. Early intervention is essential in reducing aggressive behavior and preventing a permanent cycle of violence.

- It targets children between the ages of 2 and 8 who exhibit behavioral problems or are at risk for them.

- It is led by trained facilitators who utilize "interactive presentations, videotape modeling, and role-playing techniques to encourage group discussion, problem solving, and sharing of ideas."

- The program is divided into three series: BASIC, ADVANCE, and SCHOOL. BASIC addresses parental skills such as interactive play, reinforcement skills and nonviolent discipline techniques. ADVANCE focuses on family risk factors such as depression, marital discord, and poor anger management. SCHOOL teaches ways to further youth's academic and social competence.

\section{Family Therapy}

Family therapy refers to a host of different treatment approaches linked by their common emphasis on treating the whole family rather than individuals.

Functional family therapy (Alexander and Parsons, 1982) is one form of family therapy which has been especially effective with delinquent youth. Treatment makes use of cognitive and behavioral methods to improve family relationships and increase reciprocity and cooperation among family members. Outcome studies demonstrated that functional family therapy improved family relationships and reduced recidi- vism among adolescents referred by juvenile court for offenses such as truancy, theft, and unmanageable behavior (Klein, Alexander and Parsons, 1977).

Multisystemic therapy (Henggeler, 1991) is one of the most cost-effective and demonstrably effective treatments for high-risk or delinquent children and their families. In controlled outcome studies, multisystemic therapy has proven to be superior to standard treatments for chronic juvenile offenders, innercity at-risk youth, child-abusive families, and other traditionally difficult populations. It is important that therapists faithfully adhere to MST principles and procedures for this treatment to be effective; a recent study (Henggeler, Melton, Brondino, Scherer and Hanley, 1997) found that MST effectiveness declined when therapists failed to follow the treatment model.

\section{Blueprints: \\ Functional Family Therapy (FFT)}

- FFT addresses an array of youth problems in a multisystemic method of evaluating the child's complete environment.

- FFT opposes separating youth from their families and instead advocates 12 1-hour therapy session that last at least 3 months.

- FFT includes three phases: engagement and motivation, behavior change, and generalization.

- Children who have undergone the therapy have demonstrated improved behavioral patterns.

\section{Multisystemic Therapy (MST)}

- MST is based on the understanding that youth behavioral problems can stem from an array of influences within their social network.

- MST provides therapists in the home, school, or community to provide treatment for troubled youth and their families.

- Therapists try to diagnose the source of delinquency by assessing the individual child's social influences, such as family, peers, and community. From there, therapists create intervention plans that include "strategic family therapy, structural family therapy, behavioral parent training, and cognitive behavior therapies."

- MST substantially reduces re-arrest rates and out of-home placements. 


\section{Technical Note 10}

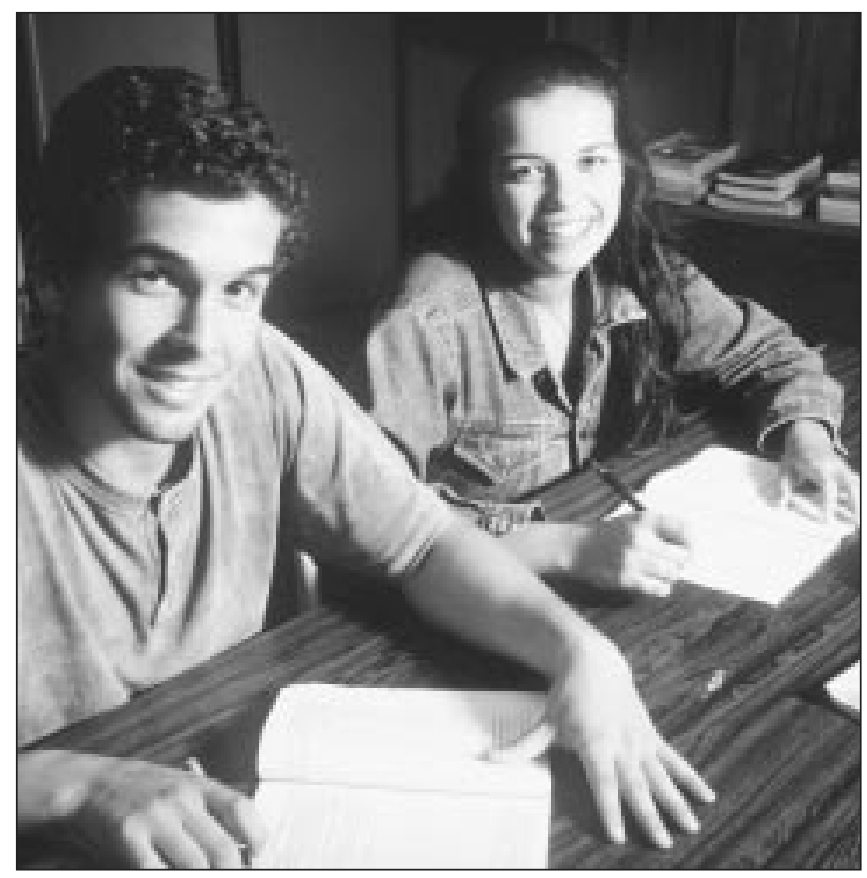

\section{Violence Prevention Counseling}

There is considerable research in support of cognitive-behavioral approaches in couseling which not only reduce aggressive behavior, but in some studies also improve school attendance and performance, and reduce substance abuse (Bry, 1982; Izzo and Ross, 1990; Lochman, 1992; Rotheram, 1982).

Violence prevention counseling can help aggressive youth cope with their frustration and hostility, and resolve conflicts without fighting. Hammond and colleagues have developed the Positive Adolescents Choices Training (PACT) program to work specifically with African-American youth (Hammond, 1991; Hammond and Yung, 1993). PACT uses culturally sensitive videotapes to teach youth social skills such as strategies for expressing and responding to criticism and negotiating solutions to disputes.

The Violence Prevention Curriculum for adolescents is part of the Teenage Health Teaching Modules (THTM) program. Developed by Deborah ProthrowStith, the curriculum lends itself to addressing issues of anger management, family violence, media violence and dating violence within the school environment. Teachers use handouts and videos to teach the program (Grossman et al.,1997).

\section{Bullying Reduction}

Bullying is a pervasive problem, which is often overlooked or minimized in schools. Because bullying is so pervasive, it is sometimes regarded as a normal or inevitable part of growing up. On the contrary, research (Boulton and Underwood, 1992; Craig, 1998; Crick, 1998; Crick and Bigbee, 1998; Furlong, Chung, Bates, and Morrison, 1995; Gilmartin, 1987; Kochenderfer and Ladd, 1996; Neary and Joseph, 1994; Slee and Rigby, 1993) indicates that school victimization has substantial and lasting effects on children's social and emotional adjustment.

Repeatedly victimized children often experience a variety of mental health problems including depression, anxiety, and low self-esteem. Victims tend to feel unsafe at school and are more likely to have school attendance problems than other students. Victims of chronic bullying continue to exhibit social adjustment problems in adulthood. Young bullies develop attitudes and values that lead to more serious aggressive behavior in adolescence. Adult tolerance for bullying sends the wrong message to children and promotes acceptance of coercion, harassment, and violence as means of controlling others.

School-wide campaigns which condemn bullying and encourage more appropriate behavior can dramatically reduce bullying, and in turn lower the likelihood of later aggression and delinquency.

\section{Blueprint: \\ Bullying Prevention Program}

- The "program's major goal is to reduce bullying among elementary, middle, and junior high school children by reducing opportunities and rewards for bullying behavior."

- School staff and administration are responsible for administrating the program at three levels. At the school level, staff administers an anonymous questionnaire to assess the nature and pervasiveness of bullying. From there, they discuss the problem, plan for program implementation, establish a school committee to supervise the plan, and develop a system of supervision. In the classroom, teachers are to enforce rules against bullying, hold classroom meetings, and encourage parent participation. At the individual level, the staff holds interventions with bullies, victims, and their parents to prevent further bullying.

- An evaluation of the program's effectiveness in 42 primary and secondary schools found a 50\% reduction in bully/victim problems, as well as marked reductions in vandalism, truancy, and fighting (Olweus, 1988). 


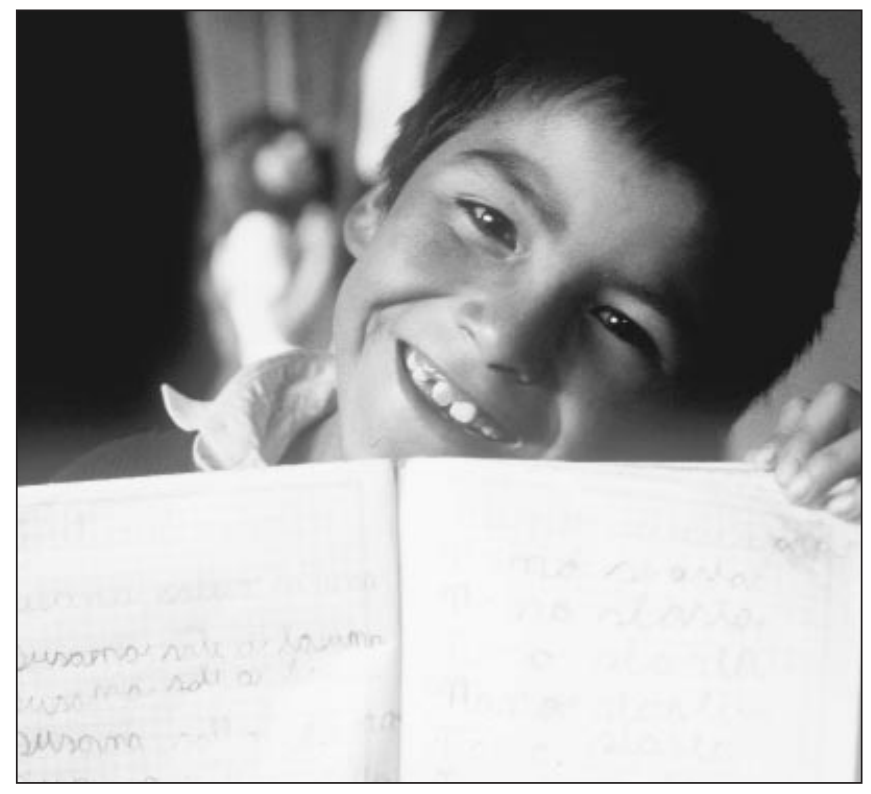

\section{Social Competence Development}

Children as young as age 4 can be taught to solve interpersonal problems in an empathic and considerate manner. Social competence generally refers to the ability to get along with others and cope with problems effectively. There are several well-designed and rigorously evaluated programs that teach social competence (Greenberg, Kusche, Cook, and Quamma, 1995; Caplan, Weissberg, Grober, Sivo, Grady, and Jacoby, 1992). One of the best-known programs in the United States is the Interpersonal Cognitive Problem Solving (ICPS, also known as "I Can Problem Solve"), which was developed by Myrna Shure and colleagues over the course of thirty-five years of research. This approach teaches children to identify problems, recognize the feelings and perspectives of others, consider the consequences of alternative solutions, and then choose the best course of action. Numerous evaluations, including multi-year follow-up studies, document that training improves children's behavior and generalizes across classroom, home, and peer situations. Children are less impulsive and disruptive, and more cooperative and prosocial with peers and adults (Shure, 1997).

PANIMOR in Costa Rica, has extensive experience in developing social skills in children. The program seeks to address the vulnerability of children and develop their human potential. Both aspects of the continuum foster the resilience of the populations served. Activities are directed to children, adolescents and adults: (www.child-abuse.com/childhouse/childwatch/key/Paniamor)
Reducing Recidivism:

Treatment of Juvenile Offenders

Rehabilitation of juvenile offenders prevents future violence by lowering recidivism and enhancing the ability of young people to become productive adults. Popular examples of rehabilitation programs include:

\section{Institutional Treatment}

Lipsey and Wilson (1997) examined 83 studies of institutional treatment for serious juvenile offenders.

Using the statistical methods of meta-analysis, they were able to identify the characteristics of the most effective programs. The most effective programs made extensive use of individual counseling and interpersonal skills training. Youth reviewed difficult social situations or past experiences, learned more skillful responses, and practiced their skills using methods such as role-playing, videotape feedback, and homework tasks. Examples of effective programs are Aggression Replacement Training (Glick and Goldstein, 1983; Goldstein, and Glick, 1994; Goldstein, Glick, Irwin, Pask-McCartney, and Rubama, 1989), the Social Interaction Skills Program (Shivrattan, 1988) and Social-Cognitive Training (Guerra and Slaby, 1990).

Notably, some popular programs were not effective. There is little evidence to support the use of wilderness/challenge programs (Lipsey and Wilson, 1997). Boot camps (also called shock incarceration) are another very popular program that has had disappointing results (Cowles, Castellano, and Gransky, 1995; Cronin, 1994; Henggeler and Shoenwald, 1994; MacKenzie and Souryal, 1994). Although offenders sent to boot camps tend to develop less antisocial attitudes while at the camp, camps have little or no effect on recidivism after return to the community.

\section{Group Homes}

Lipsey and Wilson (1997) reported that effective community residential programs provide an array of services including group and individual counseling, educational support, and vocational training. The most effective programs utilized a family home approach in which adult supervisors served as 
"teaching parents" working closely with a small number of youth. For example, Achievement Place (Kirigin, Braukmann, Atwater, and Worl, 1982; Levitt, Young, and Pappenfort, 1981; Wolf, Phillips, Fixsen, 1974) places six- to eight-year-old children with a couple who serves as surrogate parents and child advocates while administering a behaviorally oriented program. Children can return to their own homes on weekends and remain in their local schools. Achievement Place group homes are now organized according to a more general Teaching-Family Model (Bernfeld, Blase, and Fixsen, 1990). Critical to the success of group homes is the training and experience of treatment personnel and their faithful adherence to effective treatment procedures.

\section{Noninstitutional Treatment}

Lipsey and Wilson (1997) summarized the results of 117 studies of juvenile offenders treated outside of institutional settings. In general, non-institutional treatment reduces recidivism to about half the rate that it would have been without treatment (Lipsey and Wilson, 1997). A wide variety of treatment approaches were effective, with individual counseling being the most effective. Several types of counseling were beneficial, including reality therapy (Bean, 1988) and multi-systemic therapy (Bourduin et al, 1995). Training programs emphasizing interpersonal skills, parent training, and behavioral contracts also are effective (see also Guerra, Tolan, and Hammond, 1994).

Davidson and colleagues (1987) have demonstrated that at least one form of diversion from crime program for juveniles convicted of relatively minor offenses can prevent recidivism. To be effective, diversion programs should be closely supervised, with clear goals and specific interventions (Guerra, Tolan, and Hammond, 1994).

Despite some differences in treatment methods, the most effective programs have some common characteristics: greater length of treatment (generally more than the 25 weeks for all treatments), greater attention to treatment integrity (i.e., checks to make sure the therapists followed the treatment procedure), and use of mental health personnel rather than juvenile justice personnel to administer treatment.

\section{Blueprint: \\ Multidimensional Treatment Foster Care (MTFC)}

- MTFC is an alternative to youth incarceration. The program "recruits, trains, and supervises foster families to provide participating youth close supervision, fair and consistent limits and consequences, and a supportive relationship with an adult."

- MTFC is a process where trained families gradually increase the youth's freedom. At first the parents supervise the youth at all times. Then the youth gains limited free time in the community. Lastly, the youth is allowed some peer activities that require less structure.

- Parents are called daily to check the progress of the child.

- MTFC has significantly reduced recidivism visà-vis in the controlled group. 


\section{For More Information}

\section{Causes and Consequences}

CDC, http://www.cdc.gov/ncipc/pub-res/FactBook/youthviolence.htm

US Youth Violence Prevention Resource Center http://www.safeyouth.org/home.htm

National Youth Gang Center (NYGC) http://www.iir.com/nygc/

Virginia Youth Violence Prevention Program.

http://curry.edschool.virginia.edu/go/youthvio/

National Youth Violence Prevention Resource Center www.safeyouth/home.htm

Justice Information Center www.ncjrs.org

Children as Victims.

http://www.ncjrs.org/pdffiles1/ojjdp/180753.pdf

Violence and victimization Sumaries for the US. http://www.ojjdp.ncjrs.org/pubs/violencvictsum.html\# 187079

\section{Youth Violence Prevention Programs}

"Blueprint" Series.

http://www.ncjrs.org/pdffiles1/ojjdp/187079.pd

Achievement Place Program. Group Homes. http://www.h-ap.org/

Primary Mental Health Program.

http://www.sharingsuccess.org/code/eptw/profiles/48.htm

PANIAMOR www.child-

abuse.com/childhouse/childwatch/key/paniamor.html\#1

Interpersonal Cognitive Problem Solving

http://www.hamfish.org/programs/id/52

Perry Preschool Project

http://www.ncjrs.org/html/ojjdp/2000_10_1/page1.htm

Multisystemic Therapy. http://www.amicusmst.org/

Bully Prevention. http://www.lfcc.on.ca/bully.htm

Supervised Afterschool Programs.

http://www.bgca.org/programs/

http://www.safeyouth.org/topics/afterschool.htm\#overview

\section{References}

Alexander, J. F., \& Parsons, B. V. (1982). Functional family therapy. Monterey, CA: Brooks/Cole.

American Psychological Association. Violence on Television. Washington, D.C.: Author Retrieved May 14, 1997 from the World Wide Web:http://www.apa.org/pubinfo/vioelnce.html
American Youth Forum, Institute of Educational Leadership. Some Things Do Make a Difference for Youth: A Compendium of Evaluations of Youth Programs and Practices. Washington, DC. 1997

Battin, SR., Hill, K.G., Abbot, R.D.,Catalano, R.F., and Hawkins, JD. 1998 . The Contribution of gang membership to delinquency beyond delinquent friends. Criminology 36:93115

Borduin, C. M., Mann, B. J., Cone, L. T., Henggeler, S. W., Fucci, B. R., Blaske, D. M., \& Williams, R. A. (1995). Multisystemic treatment of serious juvenile offenders: Longterm prevention of criminality and violence. Journal of Consulting and Clinical Psychology, 63, 569-578.

Boulton, M.J. \& Underwood, K. (1992). Bully/victim problems among middle-school children. British Journal of Educational Psychology, 62, 73-87

Briseño Roberto y Pérez Rogelio (coordinadores). La Violencia en Venzuela: Dimensionamiento y Políticas de control. BID. No 373. Washington, DC. 1999).

Caplan, M., Weissberg, R. P., Grober, J. S., Sivo, P. J., Grady, K., and Jacoby, C. (1992). Social competence promotion with inner-city and suburban young adolescents: Effects on social adjustment and alcohol use. Journal of Consulting and Clinical Psychology, 60, 56-63.

Centers for Disease Control and Prevention, National Center for Injury Prevention and Control. The prevention of youth violence: a framework for community action. Atlanta, GA. 1993

Children's Safety Network National Injury and Violence Prevention Resource Center, Educational Resource Center, Inc. Youth violence prevention in Latino communities: A recourse guide for $\mathrm{MCH}$ professionals. Newton, MA. July 1999

Cowen, E. L., Hightower, A. D., Pedro-Carroll, J. L., Work, W. C., Wyman, P. A., with Haffey, W. G. (1996). School-based prevention for children at risk: The Primary Mental Health Project. Washington, D.C.: American Psychological Association.

Cowles, Castellano, \& Gransky, (1995). "Boot camp" drug treatment and aftercare interventions: An evaluation review. Washington, D.C.: National Institute of Justice, Office of Justice Programs, U.S. Department of Justice.

Craig, W.M. (1998). The relationship among bullying, victimization, depression, anxiety and aggression in elementary school children. Personality and Individual Differences, 24, 123-130.

Crick, N.R., \& Bigbee, M.A. (1998). Relational and overt forms of peer victimization: A multi-informant approach. Journal of Consulting and Clinical Psychology, 66, 337-347.

Cronin, R. C. (1994). Boot camps for adult and juvenile offenders: Overview and update. Washington, D.C.: National Institute of Justice.

Davidson, W. S. II, \& Redner, R. (1988). The prevention of juvenile delinquency: Diversion from the juvenile justice system. In R. H. Price, E. L. Cowen, R. P. Lorion, \& J. RamosMcKay (Eds.), 14 ounces of prevention: A casebook for practitioners (pp. 123-137). Washington, D. C.: American

Psychological Association. 
Davidson, W. S. II, Redner, R., Blakely, C. H., Mitchell, C. M., \& Emshoff, J. G. (1987). Diversion of juvenile offenders: An experimental comparison. Journal of Consulting and Clinical Psychology, 55, 68-75.

Donnerstein, Edward; Slaby, Ronald G; Eron, Leonard D. (1994). The mass media and youth aggression. In L.D. Eron, \& J.H.Gentry (Eds). Reason to hope: A psychosocial perspective on violence \& youth. (pp. 219-250.) Washington, D.C. : American Psychological Association

Dewey G. Cornell. What Works in Youth Violence Prevention Virginia Youth Violence Project. University of Virginia, 1999

L. D. Eron, J. H. Gentry, \& P. Schlegel (Eds.) Reason to hope: A psychosocial perspective on violence \& youth (pp. 383-403). Washington, D.C.: American Psychological Association

Family Services Research Center (1995). Multisystemic therapy using home-based services: A clinically effective and cost effective strategy for treating serious clinical problems in youth. Charleston, S.C.: Author.

Furlong, M.J., Chung, A., Bates, M., \& Morrison, R. L. (1995). Who are the victims of school violence? A comparison of student non-victims and multi-victims. Education and Treatment of Children, 18, 282-298.

Furlong, Michael J; Chung, Annie; Bates, Michael; Morrison, Richard L. (1995). Who are the victims of school violence? A comparison of student non-victims and multi-victims. Education \& Treatment of Children.18, 282-298.

Glick B. \& Goldstein, A. P. (1983) Aggression replacement training. Journal of Counseling and Development, 65, 356-362.

Goldstein, A. P., Glick, B., Irwin, M. J., Pask-McCartney, C., \& Rubama, I. (1989). Reducing delinquency: Intervention in the community. New York: Pergamon Press.

Goldstein, A. P., \& Glick, B. (1994). Aggression replacement training. Simulation \& Gaming, 25, 90-26.

Gottfredson C, David B. Wilson and Stacy S. Najaka. Crime, ICP 1997

Greenberg, M. T., Kusche, C. A., Cook, E. T., and Quamma, J. P. (1995). Promoting emotional competence in school-aged children: The effects of the PATHS curriculum. Development and Psychopathology, 7, 117-136.

Grossman, J. B., \& Garry, E. M. (1997). Mentoring - A proven delinquency prevention strategy. Juvenile justice Bulletin. Washington, DC: U.S. Department of Justice.

Grossman, Neckerman, Koepsell, Liu, Asher, Beland, Frey \& Rivara. (1997). The effectiveness of a violence prevention curriculum among children in elementary school. Journal of the American Medical Association, May 27, 1997.

Guerra, N. G., \& Slaby, R. G. (1990). Cognitive mediators or aggression in adolescent offenders: 2. Intervention. Developmental Psychology, 26, 269-277.

Guerra, N. G. Tolan, P. H., \& Hammond, W. R. (1994).

Prevention and treatment of adolescent violence.

Hammond, R. (1991). Dealing with anger: Givin' it, Takin' it. Workin' it out. Champaign, IL: Research Press.
Hawkins, David, Herrenkohl David, Farrington, David et al. Predictors of Youth Violence. Juvenile Justice Bulletin,U.S Department of Justice, April, 2000

Henggeler, S. W. (1991). Treating conduct problems in children and adolescents (treatment manual). Columbia, SC: S.C. Dept. of Mental Health.

Henggeler, S., W., \& Borduin C. M. (1990). Family therapy and beyond: A multisystemic approach to treating behavior problems of children and adolescents. Pacific Grove, CA: Brooks/Cole.

Henggeler, S. W., \& Shoenwald, S. K. (1994). Boot camps for juvenile offenders: Just say no. Journal of Child and Family Studies, 3, 243-248.

Henggeler, S. W., Melton, G. B., Brondino, M. J., Scherer, D. G., \& Hanley, J. H. (1997). Multisystemic therapy with violent and chronic juvenile offenders and their families: The role of treatment fidelity in successful dissemination. Journal of Consulting and Clinical Psychology, 65, 821-833.

Hoover, J., Oliver, R., \& Hazler, R.J. (192) Bullying:

Perceptions of adolescent victims in the Midwestern U.S.A. School Psychology International, 13, 5-16.

Hughes, J.N. \& Hasbrouck, J.E. (1996). Television violence: Implications for violence prevention. School Psychology Review, 25 134-151.

Institute for Educational Leadership, Some Things Do make a difference for youth, 1997

Izzo, R. L., \& Ross, R. R. (1990). Meta-analysis of rehabilitation programs for juvenile delinquents. Criminal Justice and Behavior, 17, 134-142.

Johnson, D. W., \& Johnson, R. T. (1995b). Teaching students to be peacemakers: Results of five years of research. Peace and Conflict: Journal of Peace Psychology, 4, 417-438.

Jones, M. B. \& Offord, D.R. (1989). Reduction of anti-social behavior in poor children by nonschool skill development. Journal of Child Psychology and Psychiatry and Allied Disciplines, 30, 737-750.

Kellermann, Arthur, Fuqua-Whitley et al. Preventing Youth Violence: What Works?. Annual Jounal of Public Health, 1998. 19:271-92

Kennedy, D. M., Piehl, A. M., \& Braga, A. A. (1996). Youth Gun Violence in Boston: Gun Markets, Serious Youth Offenders, and a Use Reduction Strategy.

Kirigin, K. A., Braukmann, C. J., Atwater, J. D., \& Worl, M. M. (1982). An evaluation of teaching-family (Achievement Place) group homes for juvenile offenders. Journal of Applied Behavior Analysis, 15, 1-16.

Klein, N. C., Alexander, J. F., \& Parsons, B. V. (1977). Impact of family systems intervention on recidivism and sibling delinquency: A model of primary prevention and program evaluation. Journal of Consulting and Clinical Psychology, 45, 469-474.

Klinteberg, B.A., Anderson, T., Magnusson, D., and Stattin, H. 1993. Hyperactive behavior in childhood as related to subsequent alcohol problems and violent offending: A longitudinal study of male subjects. Personality and Individual Differences $15: 381-388$ 
Kochenderfer, B.J., \& Ladd, G.W. (1996). Peer victimization: Cause or consequence of school maladjustment? Child Development, 67, 1305-1317.

Levitt, J. J., Young, T. M., \& Pappenfort, D. M. (1981). Achievement place: The teaching-family treatment model in a group-home setting. Washington, D.C.: U. S. Department of Justice.

Lipsey, M. W., \& Wilson, D. B. (1997). Effective intervention for serious juvenile offenders: A synthesis of research. Vanderbilt Institute for Public Policy Studies. Nashville, TN.

Lochman, J. E. (1992). Cognitive-behavioral intervention with aggressive boys: Three-year follow-up and preventive effects. Journal of Consulting and Clinical Psychology, 60, 426-432.

MacKenzie, D. L., \& Souryal, C. (1994). Multisite evaluation of shock incarceration. Washington, D.C.: National Institute of Justice.

McAlister, A. Juvenile Violence in the Americas: Innovative Studies in Research, Diagnosis, and Prevention. Pan American Health Organization. September, 1998

Maguin, E., and Loeber, R. 1996. Academic performance and delinquency. In Crime and Justice: A Review of Research, Vol. 20, edited by M. Tonry. Chicago, IL: University of Chicago Press, pp. 145-264

McCord, J. (1979). Some Child-Rearing Antecedents of Criminal Behavior in Adult Men. In Journal of Social Psychology, Vol. 37, No. 9, 1477-1486

Mihalic, Sharon, Irwin Katherine, et al. Blueprints for Violence Prevention. Juvenile Justice Bullentin. U.S Department of Justice, July 2001

Morrow, K.V., \& Styles, M. B. (1995). Building relationships with youth in program settings: A study of Big Brothers/Big Sisters. Philadelphia: Public/Private Ventures

Neary, A., \& Joseph, S. (1994). Peer victimization and its relationship to self-concept and depression among schoolchildren. Personality and Individual Differences, 16, 183-196.

Olweus, D. (1997). Bully/victim problems in school: Knowledge base and an effective intervention program. The Irish Journal of Psychology, 18, 170-190.

Revista Panamericana de Salud Publica. Year 78, Vol. 5, Nos 4/5 April/May 1999 "Youth violence in Latin America: current situation and violence prevention strategies". pp. 338-343

Rogers, D. 1999. Living in the Shadow of Death: Violence, Pandillas, and Social Disintegration in Contemporary Urban Nicaragua. Ph.D. dissertation, Department of Social Anthropology, University of Cambridge, UK.

Sampson, R., and Lauritsen, J. 1994. Violent victimization and offending: Individual-, situational-, and community-level risk factors. In Understanding and Preventing Violence: Vol 3, Social Influences, edited by A.J. Reiss and J.A. Roth. Washington, DC: National Academy Press, pp.1-114

Santa Cruz Giralt, M., \& Concha-Eastman, A. 2001. Barrio Adentro: La Solaridad violenta de las Pandillas. Instituto Univeritario de Opinion Publica Universidad Centroamericana "Jose Simeon Canas". San Salvador, El Salvador. Pp. 138
Schinke, S. P., Orlandi, M. A. \& Cole, K. C. (1992). Boys \& Girls Clubs in public housing developments: Prevention services for youth at risk. Journal of Community Psychology: OSAP Special Issue, 118-128.

Sheppard, D. (1999). Strategies to reduce gun violence. OJJDP fact Sheet, (No.93) Washington, D.C.: U.S. Department of Justice, Office of Juvenile Justice and Delinquency Prevention.

Sherman, L. W., Gottfredson, D., MacKenzie, D., Eck, J., Reuter, P., Bushway, S., (1997). Preventing crime: What works, what doesn't, what's promising: A report to the United States Congress. Washington, D.C.: National Institute of Justice. (Download at http://www.ncjrs.org/works/)

Shure, M. B. (1992). I can problem solve (ICPS): An interpersonal cognitive problem solving program. Champaign, IL: Research Press.

Shure, M. B. (1996a). Raising a thinking child: Help your young child to resolve everyday conflicts and get along with others. New York: Pocket Books.

Shure, M. B. (1996b). Raising a thinking child workbook. New York: Henry Holt.

Shure, M. B. (1997). Interpersonal cognitive problem solving: Primary prevention of early high-risk behaviors in the preschool and primary years. In G. W. Albee \& T. P. Gullota (Eds.), Primary prevention works (pp. 167-190). Thousand Oaks, CA: Sage.

Slee, P.T., \& Rigby, K. (1992). Australian school children's self appraisal of interpersonal relations: The bullying experience. Child Psychiatry and Human Development, 23, 273-282.

Tierney, J. P. Grossman, J. B. (1995). Making a difference: An impact study of Big Brothers/Big Sisters. Philadelphia, PA: Public/Private Ventures.

Tremblay, R. \& Craig, W. (1995). Developmental crime prevention. In Michael Tony and David P. Farrington (Eds.), Building a safer society. Crime and justice, Vol. 19. Chicago: University of Chicago Press.

Waiselfisz, J. Mapa da Violencia: Os Jovenes do Brasil. UNESCO. Rio de Janeiro: Garamond, 1998

Weaver Katherine and Maddaleno Matilde. Youth Violence in Latin America: current situation and violence prevention strategies. Pan American Jounal of Public Health. Vol 5, abril 1999 p.338-343

Wells, L.E., and Rankin, JH. 1988. Direct parental controls and delinquency. Criminology 26:263-285

Wolf, M. M., Phillips, E. L., Fixson, D. L. (1974). Achievement Place: Phase II (Vol I). Rockville, MD: Center for Studies of Crime and Delinquency, National Institute of Mental Health.

Yoshikawa, H. (1994). Prevention as cumulative protection: Effects of early family support and education on chronic delinquency and its risks. Psychological Bulletin, 115, 28-54.

Zabin LS, Hayward SC. Adolescent Sexual Behavior and Childbearing.Clin Psychol.Psychiatr.26. 8-26. 


\section{Technical Note 10}

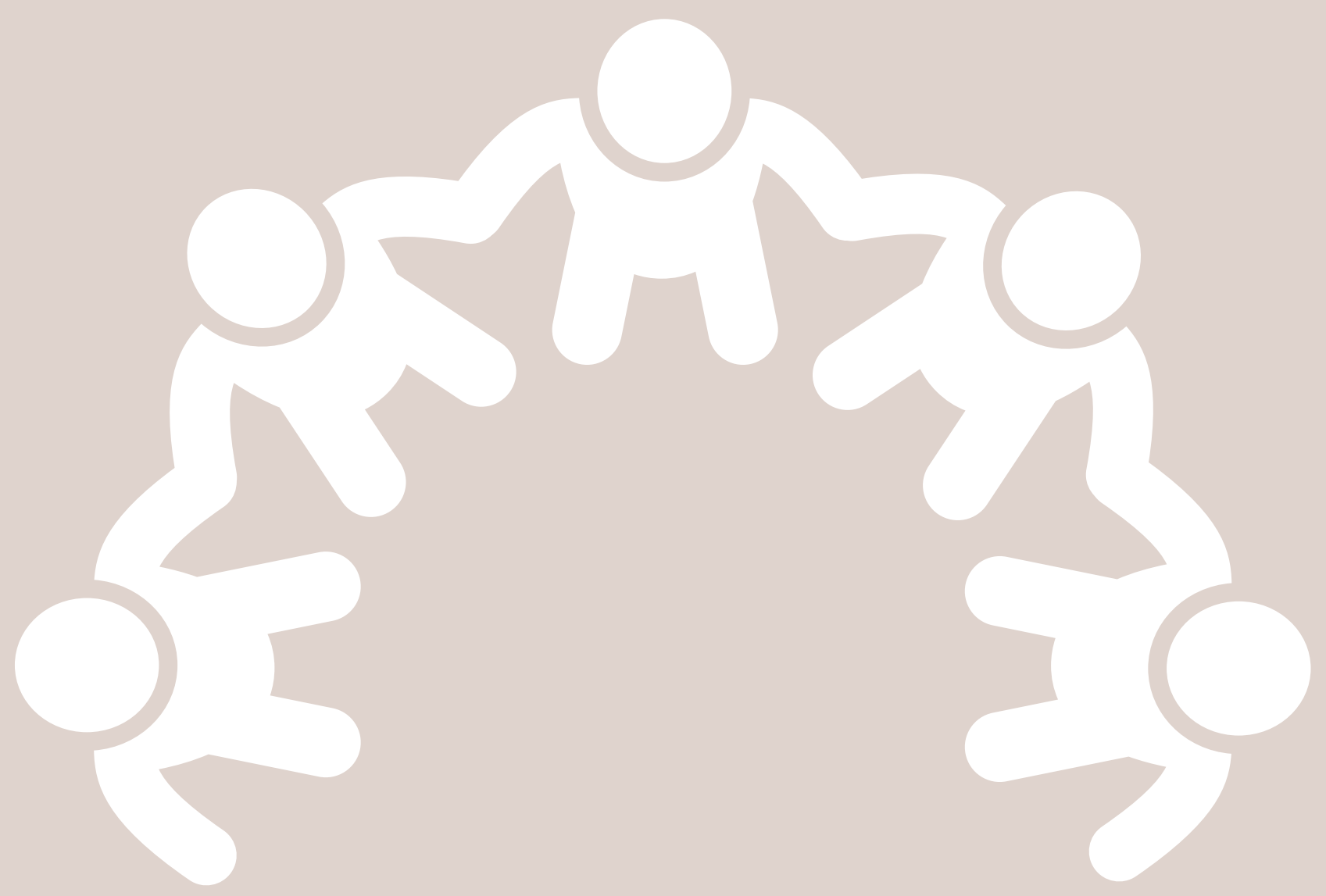

